\title{
Markus Barth on the Lord's Supper
}

\author{
Paul T. Nimmo \\ University of Aberdeen, Aberdeen, Scotland, U K \\ paul.nimmo@abdn.ac.uk
}

\begin{abstract}
This article seeks to offer the first detailed exposition and analysis of the two major writings of Markus Barth on the theme of the Lord's Supper, highlighting matters of scriptural exegesis and considering issues of theological import as well as noting its ecumenical implications. It proceeds in three main sections. First, it sets the scene for the investigation of Markus Barth's work on the Lord's Supper by considering briefly the genre and the purpose of the writings in view. Second, it engages in a close reading and analysis of both writings on the Lord's Supper. Third, and by way of conclusion, it concisely explores the wider ramifications of Barth's teaching in relation to the work of the ecumenical movement.
\end{abstract}

\section{Keywords}

Markus Barth - Lord's Supper - Jesus Christ - Passover - sacrament - ecumenism

\section{Introduction}

In recent years, a number of volumes in Reformed theology have set out a doctrine of the Lord's Supper that privileges a rather elevated understanding of the sacrament, one that emphasizes its ontological or instrumental aspects and - whether by accident or by design - readily comports with the growing consensus (and ecclesiastical pressure) of the ecumenical movement. ${ }^{1}$ There is

1 See, for example, the accomplished works by Alasdair Heron, Table and Tradition: Towards an Ecumenical Understanding of the Eucharist (Edinburgh: Handsel Press, 1983); Brian A. Gerrish, Grace and Gratitude: The Eucharistic Theology of John Calvin (Edinburgh: T\&T Clark, 1993); George Hunsinger, The Eucharist and Ecumenism: Let Us Keep the Feast (Cambridge: 
much to consider and to commend in such approaches, even as one might harbor awareness of the very particular range of resources within the Reformed tradition from which they draw support and as one might demur respectfully from some of the doctrinal emphases and insights that they highlight. ${ }^{2}$ While one might recognize its import, then, this contemporary wave of eucharistic positioning should not be taken to exhaust either the past or the present, let alone the future, of the Reformed tradition: the latter has always tolerated an explicit, if clearly circumscribed, degree of latitude in respect of its beliefs concerning the doctrine of the Lord's Supper, and indicates in its very name an ongoing willingness to revise and reform doctrines in light of the Word of God. ${ }^{3}$

One theologian who wrote about the Lord's Supper with a series of conclusions that differ strikingly from the broad trajectory identified above is the Swiss biblical scholar and theologian Markus Barth (1915-1994). Driven to fresh exegetical work on the Lord's Supper by his concerns regarding the celebration of the Lord's Supper in contemporary churches, he wrote in the course of his career both a major treatise and a lengthy volume on the Lord's Supper. ${ }^{4}$ Though scarcely engaged in detail either in his lifetime or indeed beyond, ${ }^{5}$ these texts set forth deeply informed and highly suggestive-if rather

Cambridge University Press, 2008); John W. Riggs, The Lord's Supper in the Reformed Tradition (Louisville: WJ KP, 2015); and J. Todd Billings, Remembrance, Communion, and Hope: Rediscovering the Gospel at the Lord's Table (Grand Rapids: Eerdmans, 2018).

2 These works incline strongly toward an elevated understanding of the Lord's Supper that emphasizes its mediatorial and instrumental efficacy, a tradition that embraces the work of figures such as John Calvin, Theodore Beza, John Nevin, Philip Schaff, and T.F. Torrance. Such a perspective evidently comports more easily with the traditions of Eastern Orthodoxy, Roman Catholicism, and Lutheranism. Yet, in these works there is little attention to (and even less approval of) those rather different yet hugely significant Reformed trajectories that incline toward a more symbolic approach to the Lord's Supper, as represented by scholars such as Huldrych Zwingli, Heinrich Bullinger, and Karl Barth. On the multivocity of Reformed approaches to the Lord's Supper, see Paul T. Nimmo, "Sacraments," in Cambridge Companion to Reformed Theology, ed. Paul T. Nimmo and David A.S. Fergusson (Cambridge: Cambridge University Press, 2016), 79-95.

3 Though the trope ecclesia semper reformanda est (the church is always having to be reformed) is now used by various churches, it has a particular resonance and meaning in the Reformed tradition. What is regularly overlooked, however, is the crucial qualifier secundum verbum Dei, which specifies that the (necessary) ongoing reformation of the church must take place according to the Word of God. See Michael Horton, "Reformed and Always Reforming," in Always Reformed: Essays in Honor of W. Robert Godfrey, ed. R. Scott Clark and Joel E. Kim (Escondido [CA]: Westminster Seminary California, 2010), 116-134.

4 Full bibliographical details appear below when these texts are introduced.

5 Among the predominantly negative reviews of the second work on the Lord's Supper in its German edition, see those of Rudolf Siebert in Journal of Ecumenical Studies 26 (1989): 275279; L. Lies in Zeitschrift für katholische Theologie 110 (1988): 337-340; and Jürgen Becker, 
controversial-accounts of the Lord's Supper, and merit careful attention by those from the Reformed tradition and beyond interested in constructive work on the doctrine.

In order to help overcome the lamentable neglect of the work of Markus Barth on the Lord's Supper, this article offers the first detailed exposition and analysis of his two major writings on the theme, highlighting matters of scriptural exegesis and considering issues of theological import as well as noting its ecumenical implications. ${ }^{6}$ It proceeds in three main sections. First, it sets the scene for the investigation of Barth's works on the Lord's Supper by considering in outline their genre and their purpose. Second, in the longest section, it engages in a close reading and analysis of both texts. Third, by way of conclusion, it explores the implications of Barth's teaching on the Lord's Supper for ecumenical conversations.

Markus Barth produced not one but two important works on the Lord's Supper in the course of his career. The first work is not well known and was delivered as a lecture to the Reformed convent of pastors in the canton of Basel-Country in 1945. The title was Das Abendmahl: Passamahl, Bundesmahl, und Messiasmahl (The Lord's Supper: Passover Meal, Covenant Meal, and Messianic Meal). The work appeared in print as one volume of the series Theologische Studien 7 but seems never to have been translated into English. The second work is more

Theologische Literaturzeitung 112 (1987): $75^{\circ}-75^{1}$. Though it is regularly cited within surveys of positions in respect of the Lord's Supper and finds dismissal or endorsement in swift measure in some constructive works, there appears to be little substantive engagement around either the exegetical conclusions or the theological implications of Barth's work in particular. One exception is A.H.C. van Eijk, "Ethics and the Eucharist," in Bijdragen: International Journal for Philosophy and Theology 55 (1994): 350-375, which explores the connection between the Lord's Supper and social ethics in the work of Markus Barth and Louis-Marie Chauvet. A recent online exception is the blog "The Caravan Church," which dedicated a series of posts to the English edition of Barth's second work on the Lord's Supper: see https://thecaravanchurch .wordpress.com/tag/markus-barth/, accessed April 5, 2020. And perhaps the clearest adoption and furtherance of Barth's views on the Lord's Supper is Arthur C. Cochrane, Eating and Drinking with Jesus: An Ethical and Biblical Inquiry (Philadelphia: Westminster, 1974).

6 Lack of space sadly precludes any sustained attention to either the exegetical or the theological conversation that was taking place at the respective times in which these two works were written.

7 Markus Barth, Das Abendmahl: Passamahl, Bundesmahl, und Messiasmahl, published as Theologische Studien, vol. 18 (Zollikon-Zürich: Evangelischer Verlag, 1945). 
widely known to scholarship. The basic material was first given in April 1986 in the context of public lecture series in the United States-at Pittsburgh Theological Seminary, the Theological Seminary of the University of Dubuque, and the University of Michigan. The exegetical argument underlying the lectures was published in the German monograph Das Mahl des Herrn (The Supper of the Lord) in $1987 ;{ }^{8}$ a greatly abbreviated English version of this text-a concise paraphrase rather than a straight translation - appeared the following year, in 1988, under the title Rediscovering the Lord's Supper. ${ }^{9}$

The two works demonstrate a keen knowledge of both historical and contemporary positions on the doctrine of the Lord's Supper and allude at various points to an array of dogmatic works. Moreover, they are replete with diverse comments regarding the implications of the positions adopted for the practical governance of the church and the liturgical celebration of the Lord's Supper. However, in both works the primary objects of analysis are the relevant biblical texts: the architecture of each work is structured around exegetical study, and the principal dialogue partners are scriptural scholars. Indeed, in the first work, Barth notes that "the starting point of reflection [on the Lord's Supper] must lie in exegesis,"10 while in the second work he describes his task as being "to listen to the biblical witness and the polyphonic chorus of its interpreters."11 Barth was, above all, a biblical scholar.

Barth insists that precisely theological and practical advances in respect of the Lord's Supper are to be made on the basis of exegesis-and exegesis alone. He writes: "Bible study is necessary whenever a church is open to being reformed by God's word and to rediscovering the meal instituted by Jesus Christ."12 There is thus a clear sense of the ordering of the theological disciplines-from exegesis to theology and practice. At the same, there is a profound commitment to the Protestant scripture principle, bringing in its wake

Markus Barth, Das Mahl des Herrn: Gemeinschaft mit Israel, mit Christus und unter den Gästen (Neukirchen-Vluyn: Neukirchener Verlag, 1987).

$9 \quad$ Markus Barth, Rediscovering the Lord's Supper (Atlanta: John Knox Press, 1988; repr. Eugene:Wipf \& Stock, 2006). While this English text replicates the major architectonic structures and the broad material contours of the original, at the level of the text itself there is a more sporadic correspondence. Barth himself observed that the German text "contains among other things the detailed references and arguments that could not be included in the American version and that may be sorely missed by researchers," Rediscovering, "Preface" [n.p.].

10 Barth, Das Abendmahl, 5 .

11 Barth, Das Mahl des Herrn, 5. In setting out this procedure, Markus Barth explicitly considers himself to be trying to be "faithful to the method and the way of my father [Karl Barth]," Das Mahl des Herrn, 5 .

Barth, Das Mahl des Herrn, 5 . 
significant implications in respect of the way in which Barth relativizes church tradition, even that of the early church; as will be seen below, this frequently leads Barth to a radical willingness to set the witness of scripture over against even the earliest of church traditions. ${ }^{13}$

The consequence of this exegetical focus is that Barth does not offer a treatment of the doctrine or practice of the Lord's Supper that is entirely comprehensive. In each work Barth is not primarily writing a theological treatise or practical guide, but working on biblical interpretation. However, precisely these exegetical conclusions are replete with doctrinal and practical implications, and at times Barth indicates — at least in outline - the very particular material pathways into the wider terrain of dogmatics and praxis that would result from his interpretations. In this connection, there is much to reflect upon in Barth's teaching.

The presenting issue for Barth's first major consideration of the Lord's Supper is what he describes as a "eucharistic need [Abendmahlsnot]" that is being "experienced, recognised, and even suppressed" in Christian congregations. ${ }^{14}$ Speaking to fellow pastors in October 1945, Barth suggests that the call for the Lord's Supper to be explained in the context of the life of Jesus and his escha-

13 This aspect of Barth's work will become clearer in the expositions that follow.

14 Barth, Das Abendmahl, 3. Further references to this text in this section of the article are given inline. This "need" receives detailed elucidation toward the close of the text, where the practical implications are unfolded, under the following points: 1 ) the concept of the Lord's Supper is "unclear," doctrinally because confusion reigns on account of false problems and liturgically because the whole celebration is not "impressive" enough to speak without words $(55) ; 2$ ) the celebration of the Lord's Supper is "overloaded by strange elements such as penance, absolution, the creation of a burial atmosphere and Good Friday thoughts, church discipline and all kinds of piety" (55); 3 ) the celebration is "sad and mysterious" but does not presuppose the Bible or inspire, and "knows of thanksgiving only as a supplement and a conclusion" $(55) ; 4)$ preparation and participation in the Lord's Supper has become "an individualistic business" such that "[t]he so-called world seems to understand better than the pious ones why God has created bread and wine, why a table is good and useful, how one appreciates and enjoys a meal thankfully and joyfully" (56);5) the Lord's Supper has become "a luxury" in the service of worship on account of its infrequency (56); and 6) the Lord's Supper has become an "un-Christian celebration" because "instead of the whole Christ, it is the terrible death, the sin, the forgiveness, the personal salvation, [and] the dear hope ... that have become the main elements of the Lord's Supper," in contrast with "the simple knowledge and experience of 'being with the Lord,'... [who] is 'in our midst'” (57). 
tological expectation had not yet been fully met, and that the experience of confessing Christians in Germany had precipitated "an urgent invitation to a reappraisal [Neubesinnung] of and openness to a not yet experienced blessing of the celebration of the Lord's Supper" (3). He acknowledges that a series of recent publications has "scored out old view points and indicated new ways," leading to "a certain uneasiness [ein gewisses Unbehagen] in respect of the doctrine of the Lord's Supper handed down by the Reformers" (4). And it is precisely this kind of uneasiness that, for Barth, can be productive, "if it leads to a reappraisal [Neubesinnung] of the essence and the meaning [das Wesen und den Sinn] of the Lord's Supper" (4). It is precisely such a reappraisal that Barth attempts in this lecture, at various points setting his fresh understanding of the Lord's Supper apart from the traditional positions of Roman Catholicism, Lutheranism, and the Reformed tradition. ${ }^{15}$

The starting point for Barth's reappraisal is to foreground the centrality of exegesis: in the Lord's Supper, "It is a matter of truth, not of needs," and the question of truth is "to be put to the [biblical] texts" (5). And here Barth makes a significant decision: to concentrate on the accounts of the Last Supper and their institution of the Lord's Supper in the Synoptic Gospels, focusing particularly on Mark as prior to Matthew and preferable to Luke (6), and considering other texts such as John 6 and 1 Corinthians 11 only as "commentaries" (5).

Barth's exegetical account unfolds under four theses, with theses 1, 3 , and 4 corresponding to the full title of the work as they treat in turn of the Lord's Supper as Passover meal, covenant meal, and messianic meal. Thesis 2 focuses upon the referent of the word 'this' within the Lord's Supper in light of its construal as a Passover meal. Following these exegetical theses, Barth moves to consider briefly the theological and practical implications of his work. Each of these sections of his lecture will be considered in turn in what follows.

\subsection{Passover Meal}

In the first of two theses relating to the Last Supper as a "Passover meal," Barth writes that "The Passover meal determines the character and the essence of the Last Supper of Jesus Christ" (6). It is not simply that the Last Supper-the first celebration of the Lord's Supper-is to be understood in the context of the Jewish Passover meal; it is also to be conceived as the crowning (Krönung) of the Jewish celebration of the Passover (7) ${ }^{16}$ This move is pivotal for Barth and has

15 Barth seeks in this essay to moderate critically between the Lutheran and the Reformed views, a venture whose results will be tracked in the course of the notes that follow.

16 This is only possible on the basis of the synoptic accounts. By contrast, Barth suggests, the Johannine account presents the last meal of Jesus with the disciples neither as a Passover 
two important implications. First, precisely as a Passover meal, the Last Supper is a meal of joy rather than an act or presentation of sacrifice (7). Hence the focus of the Lord's Supper cannot be on intensifying or reliving the grief felt at the death of Jesus, let alone on recalling the terrible manner of his death. By contrast, the Lord's Supper has to commemorate the joyous consequences of his death. It is a "commemorative meal [Gedächtnismahl] ... a celebration of thanks" for the event of salvation: "The one great deed of God is here and now effective [in Kraft] for those celebrating" (9). And second, precisely as a Passover meal, the Last Supper is a communal meal that serves the creation and representation of the community. Its focus is not "individual piety" (9), for the forgiveness of sins effected by the death of Jesus is "not a personal affair between God and the individual ... [but] takes place in the space and in the name of the covenant that God has concluded with his people and not with individuals" (10). In the Lord's Supper, there is gathered and presented a community - the one body of Christ — not a series of disconnected individuals.

The right understanding of Jesus's words at the Last Supper follows from the way these words are embedded in the context and actions of a Passover meal. The words of Jesus over the bread and the wine indicate, for Barth, that " $M y$ body is the true Passover meat; my blood is the true Passover blood' "-in other words, that "I am the true Passover lamb'" (13). Barth suggests, correspondingly, that "Jesus, his person, his office, his work-he is the fulfilment of the exodus from Egypt" (15). ${ }^{17}$ The result, again, is that this meal is not primarily about the manner or the fact of the death of Jesus. It is instead about "the arrival, presence, brotherhood, works, death and resurrection, recognition and faith of Jesus," all of which should be celebrated in the Lord's Supper (16).18

In his second thesis, Barth considers the words of Jesus at the Last Supper. He posits that they "do not contain any statement concerning the substance of bread and wine; they also do not explain a particular act or state within the meal as parable, symbol, or image" (17). To the question what "this" in the phrase "Do this in remembrance of me" means, Barth responds that it indicates

meal nor as the institution of the Lord's Supper; instead, John locates the it in relation to the miracle of the manna in the desert (7).

17 In light of this fulfillment, Barth writes, further celebration of the Passover meal becomes impossible (15). This is another place, however, at which Barth has later written a question mark in the margin.

18 Barth notes that given the significance of the words of Jesus as what is new about this celebration, especial interest is, with the Lutherans, to be directed to these words; yet, he adds that precisely as these words are understood as the decisive event in the Passover context of the Last Supper, so there arises the significance of the act of the Last Supper that is so emphasized by the Reformed (16-17). 
"the whole act of the meal, from the gathering at a meal in the name of Jesus, through the prayers at this meal whose content is the work of Jesus, and the eating and drinking in the community of Jesus, to the thanksgiving for God's great deed in his Son" (18). The "this" in the phrases "This is my body" and "This is my blood" similarly refers to the whole act of the meal. For Barth, these words of Jesus shed new light upon his (Passover-related) acts with the elements. In both cases, it is the use, not the substance, of the elements that is both important and clarified (20), and the use in relation to the event of the meal as a whole and not of its constituent acts. ${ }^{19}$ Jesus's revelatory words "state what actually takes place or is effected in the physical action," with the result that the visible event becomes "the physical form of the spoken Word [fleischliche Gestalt des gesprochenen Wortes]" (23).

There is here indicated an intrinsic connection between the physical event and the spiritual event. Barth notes that the power that effects this unity of revelation and form, of spiritual and material, is designated in the New Testament as the Holy Spirit, and he correspondingly writes of "the event of a divine deed in human occurrence" as "the miracle and secret of the Lord's Supper" (24). ${ }^{20}$ To designate some aspect of the Lord's Supper as merely a "sign" - whether the words, the elements, or the acts—is therefore misplaced. Instead, he writes, "the word 'is' in the words of revelation of Jesus over the bread and the wine indicates an event, which takes place here and now," an event that "according to the knowledge and will of the Father of the house who is administering, [that is,] of the Son of God is in deed and in truth more than the eating of bread and drinking of wine" $(25) .{ }^{21}$ Barth is thus emphatic that at the heart of the celebra-

19 Correspondingly, Barth questions why the Roman Catholic and Lutheran traditions in attending to the word 'This' have focused so much on the substance of the bread and wine, and why the Reformed (in the Heidelberg Catechism at least) have considered that the word 'This' picks out two separate acts in relation to each of the elements - the breaking and the eating of the bread and the pouring and the consumption of the wine-such that the words of Jesus refer to particular acts in the meal rather than the whole activity of the meal (21-22).

20 Barth writes, "In the Lord's Supper, the spiritual event that is indicated by the words of revelation and the material event that consists in the events of the meal are united in the manner of holy necessity"; he observes that one might reach for a Chalcedonian metaphor to describe this relationship, but prefers instead to relate the events of the Lord's Supper to "the Lutheran 'in, with and under'" (24).

21 This agrees with the Lutherans, according to Barth, in so far as the word 'is' cannot be "evacuated or evaporated," but disagrees with them in so far as it refers to an event and a use and not to a substance or a material (25). Barth also considers that a "basically sceptical Reformed potest ('it is possible') does not help, ... for in the Lord's Supper there does actually take place a deed of God himself" (25). 
tion of the Lord's Supper lies an event of divine activity, and posing the question of what this divine activity is in the celebration leads him to the next section. ${ }^{22}$

\subsection{Covenant Meal}

In his third thesis, Barth considers the Lord's Supper as a "covenant meal," seeking to draw a parallel with the Old Testament sacrificial meals. He begins by suggesting that when Jesus refers to his "body" and "blood," he is referring in truth to his whole human person - to "himself as the one killed, namely as the one sacrificed for many, representing a sin-offering" $(26) .{ }^{23}$ Of course, the Last Supper can only anticipate this death of Jesus: it is entirely dependent on the sacrifice that follows. But the task of the Last Supper is "to clarify the meaning of this sacrifice and impart the effect of the sacrifice" (29-30), and it achieves this in its "proclamation and publication of the power of the sacrifice of Jesus" (3o). ${ }^{24}$ The fruit of this sacrifice is that those who participate in the Lord's Supper-that is, in this "table-fellowship [Tischgemeinschaft] with Jesus" - are able to have a share in this sacrifice and in Jesus Christ $(31) .{ }^{25}$ The sharing, however, is not a sharing in the death of the one sacrificed, or in the sacrifice itself, but in the benefits of that death, as these would be celebrated in the post-sacrifice sacrificial meal. It is in this form - table-fellowship-that "Jesus wants to impart the fruit of his death to his own" (31). And so, for Barth, the meal serves not so much the forgiveness of sin as the celebration of the now-

22 There is an interesting parallel here with the work of Karl Barth on baptism that was published in the same series a couple of years earlier as Die kirchliche Lehre von der Taufe, Theologische Studien, vol. 14 (Zollikon-Zürich: Evangelischer Verlag, 1943) and appeared in English as The Teaching of the Church Regarding Baptism, translated by Ernest A. Payne (London: SCM Press, 1948). While the human side of baptism is here emphasizedChristian baptism is "in its essence a representation [Abbild] of the renewal of the human being through his participation in the death and resurrection of Jesus Christ that takes place in the power of the Holy Spirit," Die kirchliche Lehre, 3-still, "like the Lord's Supper" and other aspects of the life of the church, "it is, indirectly and mediately [indirekt und mittelbar], a free word and act of Jesus Christ himself," Die kirchliche Lehre, 8-9.

23 Barth again resists the idea that the Lord's Supper is a celebration to honor the terrible manner of the death of Jesus and correspondingly rejects the view that the breaking of the bread indicates the "breaking" of the body of Jesus. After all, as Barth observes, "the bones of Jesus were not broken" (27-28). Barth therefore rejects both the "passion play" character that leads to the (Roman Catholic) Mass and also to the typical Reformed practice (28).

24 The original published text has here "publicity [Publizität]"; Barth himself has corrected this in the archived copy to "publication [Publikation]."

25 Emphasis added. Along this line, Barth writes that Paul's words "you are proclaiming the death of the Lord" in truth mean "you are bringing to bear the salvific effect of the death of Jesus Christ" (30). 
effective reconciliation (33). On this basis-like the banquet for the prodigal son-the Lord's Supper can only be a joyful occasion.

One "new" feature of the particular covenant meal of the Lord's Supper that Barth highlights is its scope. It is "for many," for Jews and Gentiles, such that every celebration "is a renewal of this covenant and a confirmation of the constitution or new constitution of the church" (34). Here, Barth draws on the Lutheran eucharistic language in a fresh way to speak of the constitution, even reconstitution, of the church that takes place "in, with, and under" (34) the celebration of the Lord's Supper. In this context, the giving of the bread indicates "it is my sacrifice that has for you the effect that you receive life from me'" (36). ${ }^{26}$ The passing of the wine, meanwhile, has additional force, qualifying this life-giving meal as one that is joyful or celebratory. Here, then, according to Barth, the wine indicates that "'my sacrifice has effected a covenant by virtue of which you, together with the Gentiles, may stand innocent before God and may already in this world be cheerful and delighted of heart with one another'" (38). ${ }^{27}$ The meaning of the covenant meal of the Lord's Supper is thus that "Jesus ... has table-fellowship with his own and gives himself to them to eat and to drink" (38).

\subsection{Messianic Meal}

The fourth and final thesis describes the Lord's Supper as instituted by Jesus as a "messianic meal." Barth writes, "The presence of the Lord at this meal as guest and host of his own [people] makes this meal to be the presupposition, means, and promise for the existence of a community of God" (39). In his teaching, Jesus frequently refers to the messianic meal with eschatological reference. And so Barth observes in turn that "It is not just that the meal is a visible form of blessedness; blessedness itself consists in a meal" (41). At the Last Supper, Jesus promises that the next meal he will share with the disciples will be in the Kingdom of God: and so, indeed, after the resurrection his table-fellowship with them was indeed renewed (44). It is on this basis, Barth contends, that the Lord's Supper must be explained as much from these post-Easter meals as from the final Passover meal of Jesus (47).

26 This is rightly stated by the Reformed in the Heidelberg Catechism, Barth notes, though he observes that it should be made clearer in that text that it is not a feeding of the soul, but precisely the feeding of the body with earthly bread that has this great significance-and that it is therefore not "a mere symbol" (37).

27 Barth observes again that it is not the soul that drinks the wine: it is the fact that wine is truly drunk by the body that effects and proclaims "a well-founded joy and happiness" that is only possible "on the basis of forgiveness, reconciliation, covenant with God and community with the elect" (38). 
As a messianic meal, Barth observes that the Lord's Supper will always involve prayer for the coming and the presence of Jesus Christ (48). He thus surmises, "Perhaps it is not saying too much to claim that the Lord's Supper is the epitome [Inbegriff] of the gathering of 'two or three in the name of Jesus Christ" (49). Pursuing this line of thought, Barth claims that "in the Lord's Supper and only in this meal is the church constituted anew," as Jesus Christ is "truly present" by his Spirit among the participants (49). To speak of the Lord's Supper as "eschatological" is thus to indicate that the Kingdom of God "extends into time and the history of the world already," gaining "material form wherever a community celebrates the Lord's Supper" (50). This coming of the Kingdom of God is no merely human work but takes place by the miracle of the coming of Jesus in fulfillment of the will of God (50).

\subsection{Theological and Practical Implications}

Having posited and elaborated these four theses, Barth turns finally to matters directly theological and practical. In respect of the former, he notes that the purpose of his study is not to provide a "dogmatic-historical or dogmatic illumination of the question of the Lord's Supper" (51). However, he does contend that at some point between the Didache and Justin Martyr, "an actual transformation of the understanding of the Lord's Supper arose and prevailed, which departed from the biblical ground and forced foreign problems and ideas on to the Lord's Supper" $(51) .{ }^{28}$ Furthermore, he asserts, much of the tradition has been unhelpful in achieving a proper understanding of the doctrine of the Lord's Supper. ${ }^{29}$ In light of his own exegetical work, Barth observes, a dogmatic presentation of the doctrine of the Lord's Supper would receive a different aspect (53). In respect of the second, Barth offers a series of practical recommendations based on the results of his exegetical work. Though there should be nothing merely "accidental" to its celebration, nevertheless Barth suggests that " $[t]$ he best celebration of the Lord's Supper might be a celebration ... without any fixed liturgy - which does not mean that it would run without prayers, comfort, and instruction" (58). Barth offers a series of particular recommen-

28 It is thus clear that Barth upholds some version of the Hellenization thesis, though this is never detailed.

29 This is true even of the Reformers, for Barth, despite his view that there were some promising exegetical starts here and there, and despite his praise for the realism of the Lutherans and the holism of the Heidelberg Catechism. True progress that is faithful to the Reformers, yet does not follow their work slavishly, is to be achieved through exegesis (52). Barth lists a number of doctrinal questions that would have to be treated here, including: the relationships between baptism and Lord's Supper, eternity and time, and sign and matter, and how to avoid rendering the Lord's Supper a legal obligation or opus operatum. 
dations for celebrating the Lord's Supper. ${ }^{30}$ Though some of these reforms may be "contrary to tradition and at first shocking," nonetheless, Barth exhorts, "May we not pose any obstacles to the work of God!" (62-63). Finally, he appends to this published version of his lecture the text of a sample liturgy for the Lord's Supper that he has regularly used with his own congregation in Bubendorf (64$67)$.

\subsection{Summary}

Barth's first major writing on the Lord's Supper is an ambitious undertaking. At heart, he seeks to offer a response to a weighty series of concerns about church teaching and practice in respect of the Lord's Supper. And he does so by way of a fresh exegesis of a whole range of biblical materials. Aspects of his hermeneutical method and his exegetical conclusion may certainly be open to debate: Barth makes significant and contentious decisions in an almost cavalier fashion at times. However, it is clear that the grounds of that debate would be the witness of scripture. And more than this, Barth also seeks to offer a new contribution to theological understanding of the Lord's Supper, as becomes evident in his frequent references to and distancing from the triangulated views of Catholic, Lutheran, and Reformed. If the doctrinal lines are not fully developed, they are certainly traced in outline.

The pivotal decision Barth takes is to see the Lord's Supper as the telos of the Passover meal, and thus to insist upon its character as in principle communal and celebratory. At the center of the celebration of the Lord's Supper lies neither an enactment of individual piety nor a disposition of sadness at the death of Jesus Christ. Instead, in line with the Passover, what is basic to the Lord's Supper is a corporate act of memory in which the congregation recalls with joy and gratitude the reconciliation effected in Jesus Christ and engages in the covenant celebration of its present and anticipated benefits. It is Jesus Christ who is the true fulfillment of the Passover and of the exodus from Egypt that it commemorates.

30 These are: first, the celebration of the Lord's Supper is once again to become a "meal," freed from all "additions such as inquisition, church discipline, repentance, penance, absolution, [and] dramatic presentations" (6o). In this connection, second, the table must really be a table - sitting in pews leads to the suspicion that participants eat and drink as individuals, not as table-fellows (61). Third, the prayers should culminate "in the petition for the coming of the Lord and in thanksgiving" (61). Fourth, the singing should be joyful, and there should be "much singing and few words" (62). Fifth, the instruction concerning the Lord's Supper should be the same as that which is taught to confirmands (62). Finally, Barth writes, "as it is a matter at every celebration of the Lord's Supper of the reconstitution (Neukonstitution) of the community," decisions concerning the introduction of new forms of celebration should be left to the individual community (62). 
According to Barth's interpretation of the words of Jesus Christ, however, the celebration of the Lord's Supper is not simply a human act of remembrance, but also a divine act of blessing. Of especial note is the way in which Barth posits a connection between the material and the spiritual dimensions of the Lord's Supper, identifying in its celebration the taking place of both a human event and a divine event, and indeed their perfect conjunction. Thus though the Lord's Supper itself is neither a sacrifice nor the re-presentation of a sacrifice, those who participate not only remember and proclaim that sacrifice but also participate in its benefits. Hence it is wrong, Barth suggests, to speak of any aspect of the celebration as a mere sign; in truth God is at work in the Lord's Supper by the power of the Spirit. ${ }^{31}$ The Lord's Supper thus commemorates and effects the covenant blessings of the work of Jesus Christ, and it does so in the context of the enlarged covenant community of both Jew and Gentile. Indeed, for Barth, the celebration of the Lord's Supper represents the continually renewed institution of this new community in the presence of Jesus Christ, the one who is present but whose final coming is yet eagerly anticipated by this central act of table-fellowship in bread and wine.

Finally, and also of interest materially, are the relatively expansive comments of Barth on the practical implications of his view of the Lord's Supper, including the full liturgy provided. The emphasis on table-fellowship is neither an exegetical finding without further consequence, nor a theological claim without practical effect. By contrast, it demands a radical overhaul of the practical celebration of the Lord's Supper to clarify that the sharing of the table in the presence of Christ is a real and effective blessing, a participation in the coming kingdom of God, and an anticipation of the final return of Jesus Christ.

Around forty years later, around the time of his retirement from the University of Basel in 1985, Barth revisited the theme of the Lord's Supper. The presenting issue for this second major consideration of the doctrine is, once again, a "blatant need of the Lord's Supper from which no Christian can escape," in view of its current "corruption." ${ }^{32}$ It is made clear once again at the very beginning that

31 It is on this point that Barth's later theological account will diverge most substantially.

32 Barth, Das Mahl des Herrn, 1; Barth, Rediscovering the Lord's Supper, 1. Further references to the German text in this article are given inline and prefixed by $\mathrm{D}$, while further references to the English paraphrase Rediscovering are given inline and prefixed by E. A further presenting issue is noted in the German text, but is not mentioned in the English text, namely, 
Barth remains deeply dissatisfied with current church teaching and practice. ${ }^{33}$ And so he purposes to turn again to scripture for elucidation "of what the Lord's Supper was originally mean to be" (E3, cf. D5). ${ }^{34}$

The resultant exegesis seeks to cover all the major passages in the New Testament that bear implications for the Lord's Supper (E5). The volume is thus structured into four sections that consider, in turn, the themes of "Communion with Israel" (the Synoptic Gospels), "Communion with the crucified and coming One" (1 Cor 10), and "Communion among the guests" (1 Cor 11), before turning to look at "The witness to Christ of John 6." Each section will be considered in turn below.

\subsection{Communion with Israel}

The opening substantive chapter of Barth's second work on the Lord's Supper relates to the relationship between Jews and Christians in general, and between the Passover and the Lord's Supper in particular, and thus shadows the first section of his earlier work. He begins by asserting that "Gentile Christians ... cannot give thanks at the table of the Lord God without the presence, accompaniment, and participation of brothers and sisters from the people of Israel"

the possible interest in what may have been the content of Karl Barth's unwritten theology of the Lord's Supper.

33 These are identified slightly differently between the German and the English texts ( $\mathrm{D}_{1}$, E1-3). In outline, the following problems are mentioned: first, the Lord's Supper has "a somber and depressing mood" that makes its guests "tremble," rather than being a joyful celebration, and creates the impression that only "individual salvation" is in view, paying no attention to the human body, the wider society, or the whole creation (E1); second, the communion meal is no longer "an act and example of mutual sharing, caring, and love" (E1, cf. D1); third, church discourse concerning the Lord's Supper, in stark contrast to the simple language of the scripture, is obscure on account of the difficult language and concepts imported from philosophy that form "a smokescreen" (E2, cf. D44); and fourth, the Lord's Supper has served to divide congregations and churches and to provide a means of excommunication-it is ironic that "precisely the meal that is supposed to serve community and reconciliation causes more wounds and divisions than healings and reconciliations" $\left(\mathrm{D}_{1}\right)$. There is, it will readily be discerned, much overlap between these concerns and those Barth articulated in 1945 .

34 Though the introductory sections of the German and English texts are in broad harmony in (a) their initial presentation of grievances and (b) at this point of methodological intention, they differ markedly beyond this. The German text intrudes a concise reflection on Karl Barth's theology between (a) and (b) (at D2-5) and then offers a brief account of the history of theological approaches to sacrament $\left(\mathrm{D}_{5}-11\right)$ and a reflection on the potential problems of going back to scripture to resource an understanding of the Lord's Supper (D11-19). The English text, meanwhile, satisfies itself with presenting seven (clearly contestable) points of received scholarly wisdom in respect of historical-critical scholarship on the scriptural references to the Lord's Supper $\left(\mathrm{E}_{3}-5\right)$. 
(D2O, cf. E7). ${ }^{35}$ It is correspondingly of compelling importance that the Synoptic Gospels "unanimously attest that the last meal of Jesus ... was a carefully prepared and properly conducted Passover meal" (D21). Barth is well aware of the exegetical opposition that this view - a view, Barth notes, first propounded by Joachim Jeremias - has encountered, with the Passover setting of the Last Supper often instead considered to be a later accretion to an earlier tradition. But what seems to frustrate Barth most is not such opposition in itself, but rather the view that the Passover setting of the Last Supper is of no theological importance. By contrast, his own exposition brings this setting front and center, renders it the framework within which the (earlier!) Pauline accounts are to be interpreted, and posits that Passover is the context without which the Lord's Supper cannot be fully understood. This setting thus has both formal and material influence.

There follows in Barth's chapter a brief survey of the Passover in the Old Testament and in Pharisaism. He begins by observing that the celebration of the Passover "takes place in memory of, or as a memorial to, a unique, complete, and perfect act of God" (E12). While acknowledging that memory is more than simply noetic, that it also has affective, corporeal, and corporate dimensions, Barth nevertheless insists that "remembering" is not in itself effective. Correspondingly, he writes, "excluded is the idea that by remembrance, God's basic action is repeated, put into effect, validated, actualized, or applied, as if God's action were in need of, and in some sense dependent on, a religious ceremony" $\left(\right.$ E12-13). ${ }^{36}$ In other words, the Passover meal does not itself free the Israelites; it celebrates the fact that they have been freed. Crucially, this act of gratitude does not compromise the distinction between divine action and human action by identifying or conflating them (E13).

It is this conception of the Passover that, Barth contends, is assumed by Jesus at the Last Supper and is thus crucial for an understanding of the Lord's Supper. Hence both the framework and the construal of the celebration of the Last Supper-and the Lord's Supper-have their roots in the worship of the people of Israel attested in the Hebrew Scriptures. ${ }^{37}$ On this basis, Barth writes, the

35 The theme of connectedness with Israel is one of the central planks of Barth's exegesis and theology in general. Cf. his other works Israel and the Church (Richmond: John Knox Press, 1969); Jesus the Jew: What Does it Mean that Jesus is a Jew? Israel and the Palestinians (Atlanta: John Knox, 1978); and The People of God (Sheffield: Jsoт Press, 1983).

36 In case the point is not yet clear, Barth writes of the Passover as "a matter of gratitude for that which took place there-and-then, once for all time and for all those now present" (D25). 
Last Supper is "a gathering, a praying and proclaiming, an eating and drinking, in short: a joyful celebrating" (D25). At the same time, the Jewish Passover is now transformed by the words and actions of Jesus: the object of memory is no longer the historical event of the Exodus, but his person, with the feast now to be repeated in memory of him until he comes again (D25). As with the Passover, however, to speak of memory here is not to speak of "a continuous ever-new miracle that he will perform on physical elements"; rather, it is to demand "faith in himself and ... faithfulness in himself alone" (E17).

The consequence of this view is that Barth rejects a 'sacramental' view of the Lord's Supper according to which the Lord's Supper is "a means of grace" in which Jesus is "the giver and the gift ... in a unique way that is necessary for all who believe in him and want to have a share in him" (E18). To maintain otherwise is simply to ignore the Passover context of the institution of the Lord's Supper. Moreover, a 'sacramental' view ignores the fact that the language of the body and the blood of Jesus bespeaks the language of sacrifice. And "[w]hile other sacrifices must be repeated," Barth observes that "the sacrifice of Christ is once and for ever sufficient" (D28). There is thus no possibility of a presentation or re-presentation of the death of Jesus in the Lord's Supper, symbolically or otherwise.

There is a careful dialectic that Barth is pursuing here: on the one hand, the context of the Passover meal is determinative of what takes place both in the Last Supper and in the repeated celebration of the Lord's Supper, on the basis that the Last Supper is identified by scripture as a Passover meal. On the other hand, the newness and excess of the sacrifice of Jesus that the Last Supper anticipates and the Lord's Supper proclaims posits a carefully circumscribed newness and excess as intrinsic to the institution of the latter by means of the former. There is both continuity and development in view at this point.

Another way of observing this dialectic in Barth's work is to consider how he treats the language of the covenant in this context. The sacrifice of Jesus is, for Barth, "an act, a gift, a revelation made by God toward us" (E21), and more than simply referencing personal forgiveness, it also indicates a "new covenant" (E22). On the one hand, Barth writes, the blood of the covenant to which Matthew and Mark refer is "a fulfilment, a closing, a surpassing and a completion of the Old Testament conclusions of the covenant" (D29). No more blood is required within the "new covenant" effected in the sacrifice of Jesus. On the other hand, this "new covenant" does not replace or contradict the former covenant: it "is not another covenant with a different partner; it is the

tion of the Lord's Supper be said to effect any change in the elements of the kind that has proven to be church-dividing (E17). 
restitution and crowning of the original love and marriage relationship" (E24). There is no trace of a supersessionism in which Israel is replaced by the church. Indeed, for Barth, Jesus Christ "did not come to annul the Passover, but to fulfil it on feast days and ordinary days [am Festtag und im Alltag]" (D36). Thus, the relationship between the covenants is one between "glory and overflowing glory" ( $\left.D_{31}\right)$, with the "overflow" of glory of the new covenant arising from the extension of the former covenant to the Gentiles $\left(\mathrm{D}_{32}\right)$. Both the reconciliation of God with human beings and the reconciliation of human peoples with each other is thus celebrated in the Lord's Supper.

This motif of fulfillment is inseparable for Barth from the note of promise, and there is a consistent eschatological concern throughout this reflection. The death of Jesus proclaimed in the Lord's Supper is for Barth "an event that surpasses and eschatologically encapsulates all other historical experiences" (D35). What is given as a "firm promise" in participation in the Lord's Supper is that "Christ's people will be eating and drinking with their Lord at the eternal table"; in relation to this promise, the Lord's Supper is a meal for "migrants who have not yet reached their promised destination" (E25). But again, this eschatological note Barth finds to be not at all alien to the Jewish Passover feast, given that a prospective and anticipatory dimension was explicit also in its celebration (D33). Correspondingly, he writes that "Christ's coming, the Parousia, and Christ's eternal communion with God's people are the fulfilment of all promises and hopes given to Israel" (E25).

\subsection{Communion with the Crucified and Coming One}

The second major chapter of Barth's mature treatment of the Lord's Supper turns to focus on communion with Jesus Christ and moves correspondingly to consider the relevant Pauline texts from 1 Corinthians. Barth begins with the text of 1 Corinthians 10, which speaks of communion both positively (in respect of sharing in the body and blood of Christ) and negatively (in respect of sharing in the pagan altars). Of particular interest to Barth is whether Paul considers there to be a direct parallel between these two instances. For certainly, according to Barth, Paul "is fully convinced of the causative, effective, creative-in short, sacramental— power of pagan cultic actions" $\left(\mathrm{E}_{3} 6\right) .{ }^{38}$ The question thus

38 Barth observes that the "[p]agan sacrifices and holy meals miraculously join the offerers and the participants to the demons present in the sanctuaries" (E36). By contrast, he posits, "the communion tradition in which Jewish priests stood" relates to "communion with God by divine election, by birth into a chosen tribe, also by education and consecration," all of which "preceded the service at the altar," so that their share in the sacrificial meal "was a sign of the community that they were privileged to enjoy, not a means of attaining it" (E36-37). 
arises of whether Paul claims that the Lord's Supper has the same power. Put simply, as Barth writes, the issue is: "Should now the Lord's Supper be effective, creative, causative, as pagan sacrificial meals indeed were, rather than significative and proclamatory, as Israel's preservation in the wilderness and the Jewish priests' participation in sanctified food?" (E37).

On the one hand, Barth is keen not to devalue or downplay the Lord's Supper. He writes of this event as "intimate existential communion between the participants in the meal and the person of Christ crucified" (E37). In short, he writes, it is "a person-to-person relationship ... an 'encounter' and strong connection with Jesus Christ" (D56). Barth proceeds to articulate exactly what this communion means: "the death of the one Jesus Christ concerns so fundamentally those sitting at the table that they accept ... that his death is their death; that his suffering makes them willing and capable of suffering with him; that his resurrection promises theirs; that their life is in him as he is in them" (E 37$)$. At the same time, Barth insists that the word 'communion' does not mean "a joining, a common essence or function of diverse things" - "unless Paul has imposed upon it a meaning strange to Greek-speaking people" (E38, cf. $\left.\mathrm{D}_{5} 6\right)$. There is thus no notion here of any "mysterious union" (E38).

On the other hand, the question still remains as to whether participation in the sacrament is fundamentally causative or simply expressive of this communion with Christ. Barth suggests that no conclusive answer can be reached on the basis of 1 Corinthians 10 , and so he proceeds to an exposition of 1 Corinthians 11:26, in which those who celebrate the Lord's Supper are said to proclaim the Lord's death until he comes. Barth observes, first, that this proclamation is to be joyful: far from stopping at the horror of the crucified One, those who proclaim the good news also always speak of the glory of the resurrected One: "the Crucified is always the raised and living Christ" (E45). Second, far from being an individual affair, the Lord's Supper is a corporate event, because here, "the death of Christ concerns many more than a few chosen and believing people" (E46). And finally, far from being inward-looking, the Lord's Supper is "a missionary event and action" ( $\left.\mathrm{E}_{4} 6\right)$, given that "others are invited to and made welcome in it ... particularly the poor and the hungry" (D79). ${ }^{39}$

39 For Barth, correspondingly, what is being celebrated is thus "neither the mystery of the mass or the church nor the special authority of priests," but Jesus Christ alone (E47). Barth develops this latter point in further detail: in the Last Supper, he writes, the whole congregation speaks, and thus " $\mathrm{t}$ ] his verse buries the distinction between clergy and laity" (E48); and he concludes: "This meal is thus not only a crisis for every type of clericalism; it means the end of every underestimation and patronisation of so-called lay-people" (D83). 
On the basis of this latter exposition, according to Barth, the mystery of the former passage is solved. The result is that, "Boldly formulated, the Lord's Supper is a human work that God has told us to $d o$ " (E48), ${ }^{40}$ "a human work pleasing to God [ein Gott wohlgefälliges Menschenwerk]" (D83). As a work of thanksgiving, this human act of the Lord's Supper presupposes the receipt and acceptance of a gift but does not itself put that gift into effect. Barth observes that if it is "considered necessary, essential, and salutary to speak of a mediation, transmission, authentication, actualisation, or realisation of a perfect work of God and of his Son for the benefit of human beings," then one should speak not of the Lord's Supper, but of "the Holy Spirit and the role of the Word inspired by the Spirit" (D83). The Lord's Supper, by contrast, is a resounding celebration of the work of God, a joyful witness to the whole Christian community of the work of God accomplished in Jesus Christ. ${ }^{41}$

Correspondingly, for Barth, the phrase from 1Corinthians 11:26 "until he [Jesus Christ] comes" should not be taken to indicate that he comes to believers in a special way in the Lord's Supper. In this verse, Barth cautions, "the reader looks in vain for the slightest trace of a statement that the Lord comes in, or by, the breaking of the bread during the Lord's Supper" (E53). Indeed, Barth continues, there is no reference here to "an invisible presence in the hearts of the believers that would be essentially or qualitatively different from Christ's presence during preaching, prayer, singing, and charitable acts" (E53). When the text speaks of the "coming of the Lord," then, it refers to the parousia, and not to the Lord's Supper. ${ }^{42}$ The difference between the presence of Jesus Christ

40 Barth writes: "To belong to Christ, to be with him, to be assembled for worship in his name - this means at least three things at the Lord's table: (1) to give, in and as a community, thanks to God for the gift of Christ, (2) to comfort and strengthen brothers and sisters in demonstrating that Christ's death has created the bond of mutual love, and (3) to signal to all the world that God's work embraces all creatures and that the number of God's people is not yet complete" (E48).

41 At this point there is a clear parallel to Barth's earlier exegetical conclusions in respect of the understanding of baptism, in Die Taufe - Ein Sakrament? (Zollikon-Zurich: Evangelischer Verlag, 1951). There, Barth writes, "In the New Testament there is no talk—magical or mythical, causative or rational, real or kerygmatic - about a realization or a making present in connection with the performance of baptism," Die Taufe, 11, and again, "In the entire New Testament baptism is a work, which God commands people to do; with it they answer to the saving work of God and the proclamation of this saving work," Die Taufe, 523. I am grateful to the Rev. Dr David MacLachlan for these references and translations. At the same time, Barth notes wryly, "The future coming [of Jesus Christ] has becomeapart from in particular, often small groups and among so-called fundamentalists-an embarrassment" (D95). And for this reason, he laments, "The full power to be a witness to Christ ... has been converted into the claim that the church is the rich and gracious mediator of grace and salvation" ( $\left.\mathrm{E}_{54}\right)$. 
at the Lord's Supper and elsewhere in the Christian life can therefore only ever be relative. The most that can be said in this connection is that "at the table of the Lord precisely the death of the Lord for Jews, Gentiles, and the whole world is proclaimed particularly loudly and clearly" (D91).

The result of this view is that "[ $\mathrm{t}]$ he Supper is nourishment [Speisung und Tränkung] on the way of pilgrimage for a people journeying to a glorious destination" (D97, E54). It is gratitude for God's gifts, Barth suggests, that is "the basis for eating bread and drinking wine" (E56). The bread of the Lord's Supper is broken and received with thanks as a gift of God and takes place as an act of sharing together with others (E56); the wine of the Lord's Supper indicates both the need for celebration and the unavoidability of suffering (E57). In this way, and with these everyday elements and activities, the Lord's name is proclaimed and Christian faith is nourished — until Christ comes again.

\subsection{Communion among the Guests}

In the third chapter, Barth speaks of the communion among Christians celebrating the Lord's Supper, a theme already familiar from previous chapters. Barth begins by emphasizing that "two features of the Lord's Supper belong together: communion with Christ und communion among the guests" (D115). ${ }^{43}$ Put differently, in Barth's words, "Christology issues in ecclesiology" (E61). The good news that is proclaimed in the Lord's Supper irrevocably issues in a series of social and political exhortations. In exploring this connection, Barth's attention remains on the text of 1 Corinthians 10-11 and the way in which the two dimensions of communion are seen by Paul to be inseparable.

Barth begins again by highlighting that the Lord's Supper is a human and therefore an ethical act, writing that " $[\mathrm{e}]$ thics is more than an implication or a consequence of the Lord's Supper ... ethics is its home, its framework and purpose, perhaps even its essence" (E61-62). However, it is crucial at this point not to allow the message of the Gospel proclaimed in the Lord's Supper to become a demand of the law. Certainly, Barth acknowledges, that faithful celebration of the Lord's Supper implies social action lies close to the center of the biblical text. However, Barth continues, "What grounds, bears, and outshines everything social and moral is the Lord Jesus Christ himself ... [who] lives by the power of his resurrection ... [and] makes his love and his power effective through his Spirit" (D129).

43 Barth draws here an analogy to the Chalcedonian symbol and its view of the relation between the divine nature and the human nature of Jesus Christ by way of indicating the way in which the two dimensions are united "without change, without confusion, without division, without separation" (D116). 
This view lies at the core of Barth's creative claim that the ethics of the Lord's Supper is not legalistic, but instead unfolds "in an evangelical way" (E62). He writes that "its teaching is determined by the fact that Christ is Lord, that the church is Christ's people, and that each Christian has a specific function in the common praise of God and the public witness to believers and unbelievers" (E62). The result is an (evangelical) exhortation to "the coming and living together of different human beings in a way that accurately corresponds to the crucified One and his teaching" (D128).

The particular ethical dimension of the Lord's Supper arises, for Barth, out of Paul's perception that in the Christian community there are those who appear to be strong and those who appear to be weak. Paul displays an unequivocal preferential option for those who are weak and issues a corresponding ethical injunction to the strong that the weak be loved and honored. To essay this is not only to serve the weak, but also to serve Jesus Christ himself, for-as Barth observes- "The One who is to come is present among those gathering in the form of the one who is weak" (D133).

Here, then, is Barth's account of the "real presence" of Jesus Christ in the Christian life in general as attested in the Lord's Supper in particular. The consequence of this christological identification is that the neighbor must be viewed not as a law but as a gift- "present so that we might rejoice in them, not so that we have cause for acts of duty" (D135-136). When this occurs, when "the small and the weak become neighbours at the table to the allegedly great and strong," then the Lord's Supper becomes and is "a powerful and believable proclamation of the death of the Lord and a proof that the guests at the table depend upon and look forward to his return" (D136). Such unfettered and unselfish communion among the guests is one of the goals of the Lord's Supper. Barth correspondingly observes that "There is no communion with Christ, the servant of God, without mutual abasement and rendering of service to members of the community" (D139). In this way, he avers, "the meal to which Christ invites is in essence a festival of love-love for one's neighbor, which has been granted through the love and the Holy Spirit of God and Christ for all people" (E7o).

Barth is aware of the clear danger that this may all seem like a "radical and total ethicalisation, if not moralisation of the mystery of the Lord's Supper" (D141). But the problem with a correspondingly negative adjudication of his proposal lies in the way in which it identifies the pursuit of ethical conduct solely with the accrual of human merit, in quasi-legalistic fashion. By contrast, Barth writes, "as soon as the presence, discovery, and honouring of the neighbour is sought in prayer as a gift of grace and recognised with gratitude, ethics is no longer subordinate to the message of grace and faith, which God gives to the hearers of his Word" (D141). Rather than presenting a new legalistic demand, 
Barth concludes, "The neighbour and the gifts of the Spirit are a new illumination [Hereinleuchten] of the Lord who comes again, of the transformation by the Spirit from the mortal body to a spiritual body and the achievement of a new heaven and a new earth" (D141). ${ }^{44}$

In a final subsection at this point, Barth presents the ramifications of this evangelical-ethical teaching concerning the Lord's Supper for everyday life. Barth considers that the Lord's Supper "is a paradigmatic event among and for practically all daily situations," on the basis that "thanksgiving and praise also belong in daily conduct and are basic to the everyday existence of the congregation and each Christian" (E75). In evocative language, Barth notes that "[w] hat becomes visible in the Lord's Supper is the tip of an iceberg or the uppermost stone of a pyramid" (D174). The perfect sacrifice of Jesus that is proclaimed in the Lord's Supper requires no extension, application, or verification by means of human mediation. What remains instead, Barth writes, is for human beings "to show themselves to be grateful on the basis of faith in a way that impacts and determines their whole life" (D178). When celebrated appropriately, the Lord's Supper is "no fruitless work of the Law," but a matter of "active and lived love of God and of the neighbour," an "act and demonstration of gratitude," "a place of joy," and—finally also- - "a social, indeed a political action" (D179-18o). ${ }^{45}$

44 Barth here turns from Paul to Luke, offering an extended consideration of the place of meals in general and the Lord's Supper in particular within that Gospel. For all the differences that Barth identifies between them, he concludes that "Luke stands as a second witness for the same thing alongside the apostle Paul. Both connect ethics, the love of neighbour, and the community of the participants with each other most closely with the community with Christ. Neither claims that the Lord's Supper is a mystery or sacrament, through which grace and salvation are assigned and distributed and are received and possessed by each of the individual participants in the meal. In the testimony, of both, the one and only sacrament and mystery is alone Jesus Christ" (D172). Lack of space precludes further exposition and analysis of this investigation of Luke.

45 The second descriptor is particularly interesting in terms of its further characterization of evangelical ethics: "It becomes clear here [in the Lord's Supper] that in all circumstances and in all the decisions to be encountered it is a matter of a receiving, not an achieving, of a 'may' not a 'must,' of an amazing recognising, not a disrespectful explaining or manipulating" (D179). Or again, "One learns and notes here, that even the biblical imperatives ('do this ...') are a proclamation of the Gospel of Jesus Christ, a joyful message, a law of freedom" (D180). In the Lord's Supper as the paradigm of this conception, Barth suggests, "all is ethical; however only evangelical ethics—not legalistic ethics-fit and express the praise that Christians owe to God and the testimony that they are to give each other and to those who do not yet believe" (E76). 


\subsection{The Witness to Christ of John 6}

In the final major chapter of the work, Barth turns to the Gospel of John. Having demonstrated that "the New Testament contains two or three convergent testimonies concerning the Lord's Supper," he now raises the problem that "the Johannine writings seem to give not only a different but an opposite testimony on all vital issues" (E77). The issue for Barth is that many interpreters have considered this Gospel, and its sixth chapter, to set forth a sacramental view of the Lord's Supper.

The details of Barth's exegesis of John 6, as well as of four other loci in the Johannine corpus, lie beyond this article, but its main conclusions can be sketched briefly. For Barth, the key is to interpret John 6 metaphorically and not sacramentally. The text speaks of the incarnation and sacrifice of Jesus Christ, the One who brings life, and of the faith that is the proper response to himrather than of the celebration of the Lord's Supper (E94-95). Inclusion in and knowledge of this work is effected by the "double powerline or lifeline" of Word and Spirit: it is Word and Spirit—not bread and wine-that are "God's own means of grace," and Jesus Christ is the one and only sacrament (E1oo). Barth thus observes that Zwingli was well advised when he "distinguished between the unique and perfect gift of God [in Jesus Christ] and that which is given with the institution of the Supper and during this Supper" (D26o). ${ }^{46}$ The former cannot be enlarged, repeated, or realized in human activity. Correspondingly, for Barth, what takes place on feast days and everyday "can and should remind one of the once-for-all and eternal [das Einmalige und Ewige]," but should not be identified with it (D261). There should be no shift of attention from the unique gift of Jesus Christ to the sacramental act of the church. As Barth insists, no Johannine text allows one "to place alongside the one mediator of salvation a multiplicity of mediators of salvation" (D262). Therefore, although Barth acknowledges that " $[\mathrm{t}]$ he vocabulary and the substance of classical doctrines of the sacrament ... are directly anticipated in this gospel [of John]" (D263), nevertheless he is adamant that " $[\mathrm{t}]$ he one and only sacrament that is given, instituted, and blessed by God, and that is only to be received in faith, is according to this gospel [of John] called Jesus Christ" (D264). In this way, the teaching of John is deemed to comport with the teaching both of the Synoptic Gospels and of the letters to Corinth. ${ }^{47}$

46 Barth, Das Mahl des Herrn, 26o.

47 Both the German and the English texts close with consideration of Jesus Christ as the one sacrament. The English volume appends an epilogue that offers Barth's (negative) judgement on the wCC "Baptism, Eucharist, and Ministry" document of 1982 (E103-113), a document briefly (and also critically) mentioned at (D266). 


\subsection{Summary}

Barth's second major piece of research on the Lord's Supper represents a sustained and radical contribution to the history of biblical interpretation on the theme. Formally, each of the major chapters of the work involves detailed attention to a specific New Testament passage, and each offers both careful justification of its exegetical position with reference to other texts in the canon as a whole and detailed delineation of its various decisions with reference to the work of other scholars. If the result remains controversial and unacceptable in many circles, it is at least offered substantive foundation on the basis of thorough exegesis. Again, this exegesis bears clear doctrinal implications for understanding and practical implications for celebrating the Lord's Supper.

In many ways, this work builds on the foundations and insights of Barth's first essay on the Lord's Supper, and here a number of commonalities might be identified.

First, the starting point of both works is the same. This is true not only in respect of the ongoing methodological precedence accorded to the witness of scripture, but also in respect of the identical problematic issues presented regarding the celebration of the Lord's Supper. In the forty years that had passed since Barth's first work, little in the theology or practice of the Lord's Supper seems to have changed.

Second, there is the core foundational desire to understand the celebration of the Lord's Supper in light of the claim that the Last Supper was unequivocally a Passover meal. This starting point once again necessitates understanding the Lord's Supper - in line with the Passover - as a communal celebration marked by joy, rather than an individual ritual marked by sombreness. And once again it determines that the Lord's Supper-in line with the Passover-is an event not only with retrospective character, a memorial of a historic liberation, but also with contemporary significance, proclaiming the present benefits of that past liberation, and future import, in so far as it eagerly anticipates the return of Jesus Christ. There are corresponding denials in both works of any change in the elements of the Lord's Supper, of any presence of Jesus Christ in those elements, and of the Lord's Supper being in any sense either a sacrifice or the representation of a sacrifice.

At the same time, the later work of Barth on the Lord's Supper also exhibits significant and far-reaching differences from the earlier essay. Most obviously, the essay is structured in a rather different way, focusing on the central trope of communion (Gemeinschaft) and the different constituencies of communion (Israel, Christ, the guests), rather than on the central trope of a meal (Mahl) in its different iterations (Passover, covenant, and messianic). Moreover, it attends to a wider variety of biblical texts in a more systematic pattern of investigation, 
in a manner redolent of the work of an academic with years of disciplinary engagement. Some of the more contentious edges and cavalier decisions of the earlier text are now lost: this is a work of far greater depth, maturity, and erudition, for all that its conclusions will be seen below to be far more radical. In such a purposefully exegetical work, it is no surprise, however, that the practical aspects of the Lord's Supper receive less attention, and there is no accompanying liturgical order in this publication.

But there are also two significant material developments.

First, and most dramatically, the view from the first work that the Lord's Supper is a divine act is decisively repudiated in this later iteration. Gone is the language of the visible event becoming the physical form of the spoken Word, of a connection between the physical and the spiritual, of a making present of the death of Christ, of the constituting of the church, and of divine deed in human occurrence. Put simply, the Lord's Supper is no longer considered a sacrament in the traditional sense, in so far as it is no longer considered to have divine activity at its heart. Instead, it is a profoundly human activity, a response to the salvific work of God that has taken place once and for all in Jesus Christ. On this basis, it is Jesus Christ himself who is the one and only true sacrament, and there is no especial presence of Jesus Christ in the Lord's Supper that is qualitatively different from elsewhere in the Christian life.

This radical claim stems from a more thoroughgoing understanding of the Lord's Supper as a Passover meal than was the case in the earlier work. The opening contention that at the center of both Passover and the Lord's Supper lies an event of remembrance of liberation and not an event of liberation itself here dictates the shape of the theology that follows. This closer link to the Passover also serves Christians as a way into considering further conversation - and indeed necessary table-fellowship — with Jews, their partners in the divine covenant. And in addition, it relativizes, even abolishes, any sense of distinction between a privileged clerical elite with the power to preside at the Lord's Supper and members of the laity: neither the church nor its ordained are the mediators of grace or of salvation. In place of any such sacramentalism, there is simply a table at which all are called to gather in order to remember the once-for-all liberating sacrifice of Jesus. In this act of commemorative worship, they fulfill the divine service of Israel as they share bread and wine together in gratitude and joy and in communion with him. And as they are joined together in love and in service as guests at his table, they also proclaim his name as the one who will come again. ${ }^{48}$

48 For a helpful version of this summary, see particularly (D184). 
It is notable that gone also from this second work is any attempt to mediate between Reformed and Lutheran positions, or to relate the constructive proposal to a Roman Catholic position. Instead, and implicitly advancing at least some version of the Hellenization thesis, Barth offers a stark choice between following "the Greek and Latin conceptual apparatus by means of which the Lord's Supper has been thought through and considered since the second century" and returning "to such categories of speech and thought as were used in the New Testament texts composed by native Jews" ( $\left.\mathrm{D}_{4} \mathrm{O}\right)$. The consequence is that almost the entire history of the sacramental tradition-its language and its concepts, its debates and its positions ${ }^{49}$-is here rejected. Small wonder that he retrospectively observes: "my own writing on the Lord's Supper of 1945 ... moved too much in the frame of the traditional understanding of the sacraments to allow an alternative truly to become visible" (D4).

Second, there is a robust ethical turn in this later work on the Lord's Supper that comports with the emphasis upon the Lord's Supper as a fundamentally human action. Ethics is no longer an implication of the Lord's Supper but its constitutive core. Crucially, for Barth, this does not mean that the Lord's Supper becomes a legal or moral obligation: there is here no erection of a new law. Rather, the Lord's Supper now represents the paradigmatic exercise of the new evangelical ethics that accompanies the salvation freely given in Jesus Christ. Within this horizontal framework, the gospel teaching that Jesus Christ is found in the person of the one in need comes into its own, giving rise to Barth's view that the real presence of Jesus Christ is to be found in the neighborparticularly the neighbor who is in need - and that this presence is a gift to the Christian that demands loving response rather than a chore that brings moral burden. The view of the Lord's Supper as corporate event thus takes on material contours as it brings together those who are in need with those who have plenty, those who belong in the church with those who are outside, and allows for mutual respect and service in a way that proclaims the coming kingdom of God.

This renewed attention to the corporate ethical dimensions of the communion of the Lord's Supper sheds light on two additional aspects of Barth's teaching that are developed in this later work. On the one hand, for Barth, as the community that gathers round the table is participating in a fundamentally Jewish act of worship, the relationship between synagogue and church, between Jews and Christians, is not simply a matter of historical curiosity but

49 The position not only of Luther but also of Calvin is here firmly rejected; only the view of Zwingli receives honorable mention at certain points (D59, D227, D26o-261). 
becomes an issue of pressing relevance. The full unity of the people of God must be reckoned — and demonstrated — to include not only Gentile Christians but also Jews. On the other hand, the demand to love and serve the neighbor that is embodied paradigmatically in and constitutes the very essence of the Lord's Supper is posited as being determinative of the whole Christian life. This leads Barth to raise the issue of contemporary political, social, and economic relationships, and to commend these to Christians for further attention with a view to social responsibility and activist intervention on behalf of the poor and oppressed.

This article has sought to present the first concise but thorough exposition of the theology of the Lord's Supper that is presented in the two major works on the theme by Markus Barth, and to offer an initial analysis and comparison of their contents. Though the teaching of the documents runs on parallel tracks at many points, there are also clear differences as well, with the later work presenting a radical departure from the sacramental view of the Lord's Supper that is central to the earlier text. At the same time, across both works the Lord's Supper retains a centrality and significance in the life of the church, whether that be construed (respectively) as constitutive or paradigmatic. For Barth, in other words, the sacramental — or otherwise — nature of the Lord's Supper is not decisive in determining its importance.

The radicality of this position, the counter-traditional vein of the polemic that Barth on occasion unleashes in his text, poses the question of how Barth related in his day — and might yet be brought to relate today — to the ecumenical movement.

On the one hand, Barth clearly recognizes the basic necessity of ecumenical conversation. The closing words of his later work on the Lord's Supper are, "The one Shepherd of the one flock invites all people to give thanks to God at one table" (E102), and indeed, one purpose of the text is explicitly ecumenical: "A careful study of what the Lord's Supper was originally meant to be and what, after diverse developments, has become of it may contribute to the search for unity among divided churches" $\left(\mathrm{D}_{3}\right) .^{50}$ Prophetically, as noted above, he

50 Barth is well aware of the persistence among churches of "old and new suspicions and tensions, separations and exclusions" (D1), and sought to address them precisely as a theologian: "In so far as theologians also understand themselves to be members of the pilgrim people of God, they share responsibility for the unity of that people" (D182). 
also called for the inclusion of Jews within ecumenical conversations, as they belong fundamentally to the people of God. He writes: "Wherever ecumenical unity is ... sought ... Jews are indispensable participants in discussions" (E27). By contrast, where Jewish voices go unheard, there a true unity of the people of God can never be achieved.

On the other hand, however, though always open to participation in ecumenical conversation, Barth's own position is scarcely designed with ecumenical appeal in view, and he is correspondingly scathing in respect of the actual documents produced by the ecumenical ventures of his day-and there are many. He recognizes that there had been sincere and bold attempts to reach ecumenical agreement, and he mentions in his own work not only the Lima statement on Baptism, Eucharist, and Ministry (1982), but also the earlier work of conversations at Halle (1937), Arnoldshain (1957), and Leuenberg (1973). Of all these ecumenical labors, Barth is deeply suspicious: "one can ask, whether in spite of the best intentions anything more has been achieved than a mixtum compositum characterised by fatigue" (D14). He ultimately finds in all these statements nothing more than a "version of the Tertullianian and Augustinian sacramentalism and of the Greek understanding of mystery, that has spread over almost all the churches - east and west, Lutheran and Calvinist" (D15). His profound criticism of the Lima document in particular is famous, ${ }^{51}$ and there is little doubt that he would harbor similar anxieties and frustrations in respect of the successor agreement, The Church:Towards a Common Vision..$^{52}$ In respect of these views, Barth is clearly a dissenter.

Historically, as was indicated above, Barth locates the divisions of the church — and the resultant problems - in the first centuries of church history. He writes in his later work that " $[t]$ he influx of Greek dualistic philosophy, the conscious or unconscious adoption of elements of the ancient mystery religions, and accommodations to Roman legal thought and political institutions are found at the root of the divisions" $\left(\mathrm{D}_{3}\right)$. There is something of an irony here,

$5^{1} \quad$ This originally appeared as "вем: Questions and Considerations," in Theology Today 42 (1986): 490-498 and is reprinted at the end of Rediscovering the Lord's Supper, 103-113.

$5^{2}$ This has been published as The Church: Towards a Common Vision (Geneva: World Council of Churches, 2013). Note, by way of example, some of the statements of this document of which Barth could scarcely approve: that "it is also through the rites or sacraments of initiation that human beings become members of Christ and in the Lord's Supper their participation in his body (cf. 1Cor. 10:16) is renewed again and again" (§ 21); that in the Lord's Supper "Christians receive the body and blood of Christ" ( $\$ 42)$; and that the sacraments are "are visible, effective actions instituted by Christ and, at the same time, are made effective by the action of the Holy Spirit who, by means of them, equips those who receive the sacraments with a variety of gifts" $(\S 44)$. 
for the charge of dualism (along with other charges) is regularly levelled against those who, like Barth, advance a low doctrine of the sacraments, on account of their purported division of supernatural and natural, and their alleged separation of material and spiritual. ${ }^{53}$ In any event, it is for this reason that the much-vaunted ecumenical tool of ressourcement is not of fundamental import to his work. It is scripture, and scripture alone, that lies at the heart of Barth's enterprise as source and norm. Here too, then, in his refusal to concur with the widely accepted ecumenical practice of eliding scripture and tradition within a new category of "Tradition" (with a capital "T"), Barth is clearly a dissenter.

Of course, Barth knew well that in this enterprise he was plowing a rather isolated furrow. He is deeply aware that the teaching he sets forth is radically different from what is usually found in exegetical or dogmatic treatments of the Lord's Supper (D17-18), that it may not be "typically Reformed, Calvinist, or Presbyterian" (E1O2). Indeed, by his own alternative, yet modest, account, his friends on the theological road numbered Zwingli and the apostles, and that was about it. It should be noted that both then and now, this list would doubtless in truth be rather longer and include a variety of non-magisterial Reformation churches, and potentially some pentecostal or charismatic views as well. Yet even then, the vast weight of ecumenical discussion, church tradition, and vaunted and visible denominations seems to stand firmly opposed to the trajectory of Barth's work, with Barth himself being very aware that in this connection "the risk of further division in the church is enormous" (D15).

On this basis, it is difficult to conclude that the work of Barth bears much by way of promise for the ecumenical movement. That movement is on a different track, with different presuppositions and different goals, and has little interest in accounts that do not conform to the high sacramental theology that is slowly coalescing as the widely presumed and thus broadly accepted norm. Even within his own Reformed tradition, it is conformity to that broadly accepted norm that seems to have become the implicit-or even explicitgoal of much recent work on the Lord's Supper. ${ }^{54}$ The consequence of dissent, in the case of a theology of the Lord's Supper such as that of Markus Barth, is rejection, lament, and neglect. And correspondingly, it is unlikely that such a theology will make any ecumenical ground.

Even if it only be heard outside the walls of such ecumenism, however, the voice of Markus Barth on the Lord's Supper is not one that should not be silenced or ignored. For all the possible alternatives in the exegesis and theolog-

53 See, for example, Billings, Remembrance, Communion, and Hope, 120-121.

54 See the works cited in the Introduction. 
ical alternatives in the tradition, there remains an important series of lessons on show in his work-a desire to rediscover in greater depth the Jewish background of the meal, a determination not to conflate the divine and the human aspects of the celebration, and an insistence upon rendering more prominent the human, social, and political dimensions of the Lord's Supper. Perhaps above all there remains Barth's standing challenge that the one people of God irrevocably includes the people of Israel and that the latter must be included in the life of the church-and even in the Lord's Supper-in ways more constructive and more visible than have generally been undertaken so far.

Perhaps, as the ecumenical movement continues its journey, one final concern of Markus Barth might yet be contemplated. Regarding the Lima document, Barth fears that "the simple accumulation and preservation of most of the existing high sacramental and ecclesiastical doctrines ... is a device by which the churches try to boast of their riches rather than realize their poverty and repent of their errors and divisions" (E27). Related to this kind of thinking, Barth worries, is the dangerous outcome that " $t]$ he full power to be a witness to Christ ... has been converted into the claim that the church is the rich and gracious mediator of grace and salvation" (E54). It is likely that most participants in the ecumenical movement would demur strongly and angrily reject this claim as flawed analysis. But as they go forward, they might also strive to make it clearer than at least Barth found in the Lima document the need for humility in all conversation regarding the matters of God, with the openhanded and empty-handed seeking of forgiveness as the first step. As Barth concludes his response to Lima, "the road to unity begins with repentance and ... the attainment of the desired goal requires a renewed outpouring of the Holy Spirit, an unrestrained willingness to obey and follow the Lord alone, and the final coming and revelation of Jesus Christ himself" (E112).

\section{Acknowledgments}

The warm thanks of the author to Philip Ziegler and Daniel Pedersen for comments on earlier versions of this material. Any remaining infelicities are, of course, entirely the author's own. 